\title{
Politička participacija i stranačke preferencije ratnih veterana u Hrvatskoj
}

\author{
DRAGAN BAGIĆ, KRUNO KARDOV \\ Filozofski fakultet, Sveučilište u Zagrebu
}

\begin{abstract}
Sažetak
U radu se analizira posebnost veteranske populacije u Hrvatskoj po pitanju tri važna politička fenomena: političke participacije, političkih preferencija i ideološke samo-identifikacije. Rezultati analize podataka prikupljenih anketnim istraživanjem 2015. godine pokazuju da se hrvatski ratni veterani Domovinskog rata ne razlikuju od ostatka biračkog tijela u stopi političke participacije mjerene izlaznošću na parlamentarne izbore 2011. i 2015. godine te predsjedničke izbore 2015. godine. S druge strane, ratni veterani se razlikuju od ostatka biračkog tijela po političkim preferencijama i ideološkoj samoidentifikaciji, uz kontrolu drugih obilježja, i to na način da u većoj mjeri biraju stranke desnice i desnog centra te da u većoj mjeri svoju političku orijentaciju određuju kao desnu. U radu se navode i raspravljaju tumačenja te posebnosti ratnih veterana kroz tri različita pristupa koji naglašavaju selekcijsku pristranost odnosno socijalizacijske te mobilizacijske učinke.
\end{abstract}

Ključne riječi: izbori, politička participacija, političko ponašanje, političke preferencije, hrvatski ratni veterani

\section{Uvod}

U političkoj povijesti demokratske Hrvatske, kao i drugih država koje su bile prisiljene graditi demokratske institucije za vrijeme rata, ratni veterani ${ }^{1}$ imaju važno mjesto. Pored činjenice da je riječ o izravnim sudionicima Domovinskog rata, a čija se simbolička vrijednost nalazi u temeljima moderne hrvatske države, važnost ratnih veterana za političku sferu u Hrvatskoj proizlazi i iz same brojnosti te popu-

${ }^{1}$ U ovom radu se koristi termin "ratni veterani" za hrvatske branitelje iz Domovinskog rata kao tehnički termin koji je uobičajen u relevantnoj znanstvenoj literaturi. 
lacije koja čini udio od oko $10 \%$ stanovništva. ${ }^{2}$ Ako ratnim veteranima pribrojimo i članove njihovih obitelji, veteranska populacija postaje potencijalno najbrojnija interesna skupina u kompeticiji za društveni status, materijalne beneficije i različite socijalne usluge. Na to da je riječ o politički važnoj društvenoj kategoriji upućuje i postojanje posebnih tijela zaduženih za veteranska pitanja u hrvatskoj izvršnoj i zakonodavnoj vlasti, kao što su Ministarstvo hrvatskih branitelja i Saborski odbor za ratne veterane. Svjedoci smo također i relativno dugotrajne prisutnosti različitih tema vezanih uz Domovinski rat u predizbornim kampanjama kojima političke stranke nastoje taj dio biračkog tijela mobilizirati ili pak alijenirati s ciljem izborne apstinencije.

Ipak, unatoč visokoj razini javne vidljivosti hrvatskih ratnih veterana u političkom životu, postojanju posebnog sustava socijalne skrbi ili visokoj simboličkoj vrijednosti veteranske populacije u hrvatskom društvu političko ponašanje ratnih veterana jedna je od najmanje istraživanih tema. Rijetke prethodne studije koje su se bavile mobilizacijom hrvatskih ratnih veterana u političkoj sferi primarno su za predmet analize uzimale veteranske proteste i mobilizaciju ratnih veterana kroz udruge civilnog društva (Fisher, 2003; Dolenec, 2014) ili su pak generirale teorijske hipoteze kao što je hipoteza o klijentelističkom odnosu veteranske populacije i pojedinih političkih stranaka (Kasapović, 2001; Stubbs i Zrinščak, 2012). Zajedničko je većini tih studija promatranje ratnih veterana kao homogenog političkog tijela i biračkog bloka u pravilu desnih političkih stranaka.

Cilj ovoga rada je popuniti tu prazninu i istražiti posebnost veteranske populacije u Hrvatskoj po pitanju tri važna politička fenomena: političke participacije, političkih preferencija i ideološke samo-identifikacije. Taj segment političkog ponašanja i stavova ratnih veterana i ne-veteranske populacije se u radu analizira kroz anketne podatke o sudjelovanju na parlamentarnim izborima 2011. i 2015. godine te predsjedničkim izborima 2015. godine. Rad je nastao u okviru projekta "Veteranske politike i dinamika organiziranja ratnih veterana u Hrvatskoj" koji je financiran sredstvima Sveučilišta u Zagrebu.

\section{Ratni veterani i političko ponašanje}

Istraživanja političkih stavova i ponašanja ratnih veterana imaju relativno dugu povijest, a sustavna istraživanja pokrenuta su u SAD-u neposredno nakon II. svjetskog rata. Uloga veterana iz I. svjetskog rata u usponu nacističkog pokreta u Njemačkoj kao i nedovoljna istraženost društvene uloge vojske kao institucije zabrinule

${ }^{2}$ U Registru hrvatskih branitelja iz Domovinskog rata krajem 2013. godine nalazilo se 503.112 ratnih veterana (Vlada RH, 2014). Prema Popisu stanovništva iz 2011. godine u Hrvatskoj su registrirana 419.922 ratna veterana iz Domovinskog rata (Šućur, Babić i Ogresta, 2017). 
su mnoge u SAD-u da bi ratni veterani mogli predstavljati izazov za građansku kulturu, demokratski poredak i političke institucije te da bi ratni veterani po završetku rata mogli negativno preobraziti američko društvo. Smatralo se, naime, da ratno iskustvo i vojna organizacija građane transformiraju u toj mjeri da im ideje demokracije, tolerancije i miroljubivog rješavanja problema postaju strani. To je primjerice vidljivo iz istraživačkih hipoteza iznesenih u studiji Dinamika predrasu$d a$ Bettelheima i Janowitza (1950) u kojoj su veterani bili izdvojeni kao specifična društvena skupina kojoj se trebalo posebno posvetiti unutar šire serije istraživanja o autoritetu, antisemitizmu, rasizmu i netoleranciji. Ta istraživanja su često u podlozi imala nedovoljno jasan koncept militarizma i u pravilu nisu potvrđivala istraživačke pretpostavke. Prijelaz na dobrovoljnu vojsku u SAD-u je sedamdesetih godina prošlog stoljeća dao novi poticaj istraživanjima utjecaja vojske kao institucije na političke stavove i preferencije građana. Ta istraživanja su bila čvršće orijentirana prema ustanovljavanju razlika između veteranske i ne-veteranske populacije glede pitanja političkog cinizma te političkih stavova i preferencija. Većina je tih studija $\mathrm{u}$ pravilu bilježila razlike $\mathrm{u}$ iskazanim političkim stavovima veterana i ostalih, no uz kontrolu varijabli poput dobi, spola, obrazovanja i socio-ekonomskog statusa te razlike bi nestajale po većini pitanja, osim onih koja su se izravno ticala same vojske (Jenning i Markus, 1977; Schreiber, 1978). Slični su bili i rezultati novijih istraživanja koja su u većoj mjeri uzimala u obzir različite dobne skupine odnosno veteransku populaciju različitih ratova (Teigen, 2012). Ipak, čini se da najnovija generacija američkih ratnih veterana donosi neke promjene. Dok su politički stavovi i preferencije ratnih veterana na američkim predsjedničkim izborima 2004. godine još uvijek bili u skladu sa stavovima opće populacije (Teigen, 2007), a i istraživanja rađena na starijim generacijama veterana pokazivala su istovjetne političke vrijednosti i stavove, istraživanja provođena na novijim političkim izborima i s uključenjem novijih generacija veterana pokazuju da više nije tako. Američka je veteranska populacija postala više konzervativno orijentirana, u većoj se mjeri identificira $s$ Republikanskom strankom i više podržava upotrebu vojne sile od ostatka populacije (Klingler i Chatagnier, 2014; Leal i Teigen, 2015).

Istraživanja političkih stavova i preferencija veteranske populacije karakteristična su za SAD, a mnogo se manje provode u drugim zemljama. U europskim zemljama razloge za to nalazimo u relativno kasnom ukidanju opće vojne obveze, dok u postkonfliktnim zemljama to jednim dijelom može biti posljedica specifičnih politika međunarodnih organizacija koje ratne veterane promatraju kao privremenu političku kategoriju koja bi trebala nestati nakon ponovne "integracije u društvo".

Za razliku od istraživanja političkih stavova, istraživanja političke participacije su brojnija i provedena su u različitim društvenim i političkim kontekstima. Rezultati istraživanja političke participacije u pravilu pokazuju da ratni veterani češće izlaze na izbore te da su više zainteresirani za sudjelovanje u političkim i gra- 
đanskim aktivnostima. Te razlike neki autori objašnjavaju ratnim i vojnim faktorima, naglašavajući pritom utjecaj socijalizacije, a drugi poslijeratnim i poslijevojnim faktorima, naglašavajući pritom utjecaj raznih programa za veterane. Tek se rijetko koriste selekcijskim faktorima. Treba istaći da između ratnih i poslijeratnih faktora često nema dovoljno jasne razlike, što pokazuje slučaj političke mobilizacije ratnih veterana oko veteranskih beneficija (Söderström, 2015). Jedan od primjera analize poslijeratnih utjecaja jest studija Suzanne Mettler (2002) o povratnim učincima specifičnih socijalnih veteranskih politika u SAD-u. Istražujući političku participaciju ratnih veterana II. svjetskog rata i korištenje različitih socijalnih programa namijenjenih toj društvenoj skupini, autorica pokazuje da su poslijeratni veteranski programi doprinijeli povećanju političke participacije te da su najviše utjecali na niže društveno-ekonomske slojeve. Veteranski socijalni programi su upravo deprivilegiranim društvenim skupinama osigurali temeljne pretpostavke za povećanje socijalnog kapitala i kompetencija važnih za političku participaciju (Mettler, 2002). Slično zaključuju Nesbit i Reingold (2011), koji do takvog zaključka dolaze istražujući vojnu socijalizaciju odnosno povezanost vojne službe i volontiranja. Po njima je vojska odigrala presudnu ulogu u povećanju društvenih resursa i vještina veterana koje su potrebne za aktivni građanski život. Iskustvo vojne službe pozitivno korelira s volontiranjem, naročito u slučaju afroameričke i latinoameričke populacije. Pokazuje se da veterani s ratnim iskustvom češće volontiraju u društvenim i političkim aktivnostima od vojnika mirnodopske vojne službe (Nesbit i Reingold, 2011). I neka druga istraživanja koja govore o višim razinama političke participacije pojedinih društvenih skupina veterana, kao što su afroamerički (Ellison, 1992; Parker, 2009) odnosno latinoamerički (Leal, 1999) veterani, smještaju objašnjenja u sličan okvir.

Da nije riječ samo o fenomenu rezerviranom za deprivilegirane društvene skupine pokazuje studija Jeremya M. Teigena (2006) koja je obuhvatila različite veteranske kohorte odnosno američke veterane iz različitih oružanih sukoba. Važnost je te studije, koja je analizirala izlaznost američkih veterana na izbore od 1972. do 2004. godine, između ostaloga i u tome što za američki kontekst otklanja selekcijsku pristranost kao objašnjenje za višu stopu političke participacije (npr. da oni koji se pridružuju vojsci a priori u većoj mjeri izlaze na izbore zbog više razine patriotizma, altruističkog ponašanja ili nekog drugog faktora koji prethodi vojnoj službi). Kako pokazuje ta studija, kad bi bila riječ o utjecaju selekcije, a ne socijalizacije, postojale bi razlike između veterana prije i nakon 1974. godine od koje vojsku popunjavaju dobrovoljci, no to podaci ne potvrđuju. Upravo suprotno, primarni razlozi povećane participacije ratnih veterana nalaze se podjednako u generacijama opće vojne obveze i u generacijama dobrovoljne vojske (Teigen, 2006).

Unutar socijalizacijske paradigme razvili su se različiti teorijski pristupi - od onih koji polaze od institucionalne socijalizacije i resursno-mobilizacijskih pristupa ili pak teorija socijalnog kapitala do onih koji govore o specifičnim učincima sudje- 
lovanja u oružanoj borbi i izloženosti kolektivnom nasilju. Prvi objašnjenja temelje na ideji vojske kao škole nacije koja pojedincima usađuje patriotske ideale i druge vrijednosti i norme, a koje se prenose u kasniji život veterana i doprinose povećanju političke participacije. Slično kao što obrazovanje promiče stavove o građanskim dužnostima, i vojno iskustvo i iskustvo djelovanja na ispunjenju zajedničkih ciljeva mogu utjecati na drukčije razumijevanje troškova i koristi od političke participacije. Pritom se kroz vojsku mogu steći vještine koje su relevantne i za političku aktivnost, od organizacijskih i upravljačkih vještina do osjećaja građanske dužnosti i odgovornosti (Nesbit i Reingold, 2011; Ellison, 1992; Parker, 2009; Leal, 1999; Teigen, 2006).

S druge strane, tumačenja koja naglašavaju specifično iskustvo izloženosti nasilju i sudjelovanja u oružanoj borbi često nalaze inspiraciju u novijim istraživanjima ratne traume i konceptu postraumatskog rasta. Naime, osim negativnih učinaka, izloženost nasilju može proizvesti i pozitivne učinke poput promjena u osobnim prioritetima, osjećaja veće snage i samopouzdanja, veće prilagodljivosti i iskazivanja novootkrivenih sposobnosti i kvaliteta (Tedeschi i Calhoun, 2004). Tako su među onim američkim veteranima Korejskog i II. svjetskog rata koji su imali borbeno iskustvo zabilježeni manji osjećaj bespomoćnosti i viša otpornost u srednjoj životnoj dobi u odnosu na veterane bez borbenog iskustva (Elder i Clipp, 1989). O povezanosti viktimizacije i poslijeratnog političkog ponašanja govori i istraživanje provedeno u Sierra Leoneu gdje je zabilježena veća politička participacija među civilima iz domaćinstava koja su doživjela ratno nasilje, i to bez drugih socio-ekonomskih promjena u toj populaciji (Bellows i Miguel, 2009). Slične nalaze donosi i istraživanje provedeno među bivšim borcima u Ugandi gdje je ustanovljeno da nasilno unovačeni bivši borci glasaju na izborima $27 \%$ češće od ostalih građana te da se dvostruko više angažiraju u vođenju zajednica. Učinci koje iskustvo nasilja ima na participaciju u izborima su i ondje primarno politički, pa izloženost nasilju nije utjecala istovremeno i na nepolitičke oblike društvenog djelovanja (Blattman, 2009).

U Hrvatskoj još nema sličnih istraživanja. Uvidi u političko ponašanje i političke stavove ratnih veterana u Hrvatskoj su u većoj mjeri anegdotalnog karaktera i uglavnom ne proizlaze iz empirijskih istraživanja koja bi nastojala utvrditi postoji li posebnost veteranske populacije u odnosu na druge građane.

\section{Metodologija istraživanja}

Cilj ovog rada je ustanoviti postoji li i - ako postoji - opisati posebnost veteranske populacije u Hrvatskoj po pitanju političke participacije, političkih preferencija i ideološke samo-identifikacije. Na temelju dosadašnjih spoznaja o političkom ponašanju i stavovima veteranske populacije i rezultata istraživanja provedenih u drugim zem- 
ljama odredili smo tri hipoteze: 1) da ratni veterani posjeduju višu stopu političke participacije od ne-veteranske populacije, 2) da ratni veterani preferiraju stranke desnice i desnog centra u podjednakoj mjeri kao i pripadnici ne-veteranske populacije uz kontrolu utjecaja socio-demografskih i socio-ekonomskih obilježja i 3) da se ratni veterani ideološki samo-identificiraju podjednako kao i pripadnici ne-veteranske populacije uz kontrolu utjecaja socio-demografskih i socio-ekonomskih obilježja.

Podaci koji se $\mathrm{u}$ radu koriste prikupljeni su anketnim istraživanjem metodom intervjua licem-u-lice u okviru omnibus istraživanja agencije Ipsos. Podaci su prikupljeni u tri vala omnibus istraživanja, u srpnju, rujnu i listopadu 2015. godine, kako bi se osigurao dovoljan poduzorak ispitanika s veteranskim statusom. Prikupljanje podataka u svakom od valova provedeno je okvirno između 1. i 15. u mjesecu prema istoj metodologiji. Za svaki je val dizajniran zaseban dvo-etapno stratificirani više-etapni klaster uzorak od 1000 ispitanika starijih od 15 godina. Primarna jedinica uzorkovanja bilo je naselje unutar stratuma, druga jedinica uzorkovanja bile su četvrti ili dijelovi naselja, a treća jedinica kućanstva. U sve tri etape klasteri su birani odgovarajućom metodom slučajnog izbora. Uzorak je stratificiran prema regiji te veličini naselja, a njegova struktura je usklađena sa strukturom populacije s obzirom na spol, dob, stupanj obrazovanja i radni status ispitanika kroz proceduru utežavanja RIM metodom. Nakon provedenog utežavanja struktura uzorka nije statistički značajno odstupala od strukture populacije prema navedenim obilježjima. U analizu je ukupno ušlo 2.889 ispitanika starijih od 18 godina, od kojih je 320 iskazalo status hrvatskog branitelja upisanog u Registar hrvatskih branitelja. ${ }^{3}$

Za potrebe ovog rada korištene su tri skupine pitanja: 1) o političkom ponašanju i preferencijama, 2) o veteranskom statusu i iskustvima te 3) o socio-demografskim i socio-ekonomskim obilježjima ispitanika. Socio-demografska (spol, dob, regija i veličina naselja) i socio-ekonomska obilježja (radni status, stupanj obrazovanja, zanimanje i dr.) su u analizi korištena kao kontrolna obilježja s obzirom na to da se veteranska populacija po njima značajno razlikuje od ostatka populacije. Skupine pitanja su u omnibus anketnom upitniku slijedile jedna za drugom. Iz skupine pitanja o političkom ponašanju i preferencijama u radu su korištene sljedeće varijable: je li ispitanik izašao na parlamentarne izbore 2011. godine; ako jest, za koju listu je glasao na tim izborima; je li ispitanik izašao na izbore za Predsjednika Republike Hrvatske u drugom krugu koji je održan početkom 2015. godine; ${ }^{4}$ ako

3 Navedeni su brojevi ispitanika prije primjene postupka utežavanja.

${ }^{4}$ Prikupljeni su podaci o izlasku i u prvom krugu predsjedničkih izbora, no u radu se koristi samo podatak o izlasku u drugom krugu jer je izlaznost tada bila značajno veća $(59,1 \%$ u odnosu na $47,1 \%$ ) te je u pogledu političkih svjetonazora struktura kandidata u drugom krugu bila znatno jasnija s obzirom na to da su birači birali između jednog kandidata ljevice i lijevog centra (Ivo Josipović) i jedne kandidatkinje desnice i desnog centra (Kolinda Grabar-Kitarović). 
jest, za kojeg kandidata/kandidatkinju je glasovao; namjerava li ispitanik izaći na parlamentarne izbore koji su zakazani za studeni 2015. godine; i za koju stranku misli glasati na tim izborima; te politička samo-identifikacija ispitanika na skali od krajnje lijevo (1) do krajnje desno (7). Iz navedenih pitanja izveden je indeks političke participacije. Indeks političke participacije predstavlja broj nacionalnih izbora na kojima je ispitanik glasovao ili je iskazao namjeru izlaska na izbore (u slučaju parlamentarnih izbora 2015. godine) te se njegova vrijednost kreće od 0 do 3. ${ }^{5}$ Taj indeks je konstruiran samo za ispitanike starije od 21 godine jer mlađi nisu imali mogućnost sudjelovanja na svim promatranim izborima. S obzirom na to da su svi veterani Domovinskog rata stariji od 21 godine, te su stoga imali mogućnost sudjelovanja na svim promatranim izborima, usporedba između veterana i ostatka populacije ne bi bila analitički ispravna da je indeks konstruiran za sve ispitanike.

U radu su korištena dva pitanja iz skupine pitanja koja se tiče veteranskog statusa i iskustava: ima li ispitanik status hrvatskog branitelja prema Registru hrvatskih branitelja te je li ispitanik (bez obzira ima li status hrvatskog branitelja ili ne) preživio neku ratnu traumu (napuštanje doma duže od 30 dana zbog ratne opasnosti, manje oštećenje nekretnine u kojoj je živio, potpuno ili značajno oštećenje nekretnine u kojoj je živio, ranjavanje bližeg člana obitelji, pogibelj bližeg člana obitelji, zatočeništvo bližeg člana obitelji). U analizi su iz dva navedena pitanja kreirane dvije binarne varijable: ispitanik ima/nema status branitelja te ispitanik jest/nije doživio neku od navedenih ratnih trauma.

Iz skupine pitanja koja su se ticala socio-demografskih i socio-ekonomskih obilježja ispitanika u radu su korištena sljedeća pitanja: spol, dob, stupanj obrazovanja (varijabla s 11 stupnjeva), veličina naselja (varijabla s 4 kategorije), regija, radni status te učestalost odlaska na vjerske obrede (od "nikada" - 1 do "svakog dana" 7). U analizi je varijabla spol binarizirana tako da su žene imale vrijednost 0 , a muškarci 1. Iz pitanja o regiji kreirana je nova binarna varijabla ratna regija u kojoj su vrijednost 1 imale one regije koje su bile izravno zahvaćene ratom (Slavonija, Lika, Kordun, Moslavina i Banovina te Dalmacija), dok su ostale regije imale vrijednost 0 . Iz pitanja o radnom statusu kreirane su tri binarne varijable: zaposlen (1 ako je ispitanik u radnom odnosu, bilo samozaposlen ili ovisno zaposlen), umirovljenik ( 1 ako je ispitanik u mirovini) te nezaposlen (1 ako ispitanik ima status nezaposlene osobe). Ostale kategorije radnog statusa (studenti, poljoprivrednici i dr.) su u sve tri binarne varijable kodirane kodom 0 .

${ }^{5}$ Kada su u pitanju parlamentarni izbori 2015. godine, istraživanje je provedeno u razdoblju od nekoliko mjeseci prije njihovog održavanja te smo pri konstrukciji indeksa u obzir uzeli samo ispitanike koji su na pitanje o namjeri izlaska na te izbore naveli da će sigurno ili vjerojatno izaći. Obje skupine su imale vrijednost 1 pri konstrukciji indeksa političke participacije. 


\section{Rezultati}

Politička participacija braniteljske populacije

U ovom radu kao indikator političke participacije veteranske populacije koristimo sudjelovanje na nacionalnim izborima koji su održani između početka 2011. i kraja 2015. godine. U ukupnom uzorku je $66,7 \%$ ispitanika starijih od 21 godinu navelo da je izašlo na sve izbore (tri) u tom periodu, dok $12,5 \%$ nije izašlo ni na jedne od navedenih izbora (tablica 1). U prosjeku su ispitanici izašli na 2,3 izbora od promatrana tri. Između ispitanika sa statusom veterana i ostatka uzorka nema statistički značajne razlike u prosječnoj vrijednosti na indeksu političke participacije $(\mathrm{t}=-1,129 ; \mathrm{df}=2654 ; \mathrm{p}=0,259)$. Statistički značajna razlika $\mathrm{u}$ iskazanoj participaciji na izborima između ratnih veterana i ostatka uzorka nije utvrđena ni za jedne pojedinačne izbore. ${ }^{6}$ Status branitelja ostaje statistički neznačajan prediktor političke participacije i kada se u binarnoj logističkoj regresiji kontrolira utjecaj drugih obilježja ispitanika, kao što su spol, dob, stupanj obrazovanja, radni status (kroz tri binarne varijable), veličina naselja, prebivanje u regiji izravno zahvaćenoj ratom, izloženost ratnim traumama te učestalost odlaska na vjerske obrede (tablica 2 na sljedećoj stranici). ${ }^{7}$

Tablica 1. Indeks političke participacije: usporedba veterana i ne-veterana (\%)

\begin{tabular}{|c|c|c|c|}
\hline Vrijednost & Cijeli uzorak & Ne-veterani & Veterani \\
\hline 0 & 12,5 & 12,6 & 11,6 \\
\hline 1 & 6,9 & 7,1 & 5,8 \\
\hline 2 & 13,9 & 14,0 & 12,8 \\
\hline 3 & 66,7 & 66,2 & 69,9 \\
\hline Prosjek & 2,3 & 2,3 & 2,4 \\
\hline
\end{tabular}

Napomena: samo ispitanici stariji od 21 godine.

${ }^{6}$ Parlamentarni izbori 2011. godine: $\chi=1,71 ; \mathrm{df}=1 ; \mathrm{p}=0,191$. Drugi krug predsjedničkih izbora 2015. godine: $\chi=2,39 ; \mathrm{df}=1 ; \mathrm{p}=0,122$. Namjera izlaska na parlamentarne izbore 2015 . godine: $\chi=0,91 ; \mathrm{df}=1 ; \mathrm{p}=0,340$.

${ }^{7}$ Provedena je i linearna regresijska analiza s indeksom političke participacije kao zavisnom varijablom i istim sklopom nezavisnih varijabli, koja je ukazala na isti zaključak. Status branitelja ostaje statistički neznačajan prediktor političke participacije i kada se kontrolira utjecaj sociodemografskih i socio-ekonomskih obilježja $(\mathrm{t}=0,741 ; \mathrm{df}=2654 ; \mathrm{p}=0,459)$. 
Tablica 2. Rezultati binarne logističke regresije s participacijom na pojedinim izborima kao zavisnom varijablom (Beta)

\begin{tabular}{|c|c|c|c|c|c|c|}
\hline & \multicolumn{2}{|c|}{$\begin{array}{l}\text { Parlamentarni izbori } \\
\text { 2011. godine }\end{array}$} & \multicolumn{2}{|c|}{$\begin{array}{c}\text { Drugi krug } \\
\text { predsjedničkih izbora } \\
\text { 2015. godine }\end{array}$} & \multicolumn{2}{|c|}{$\begin{array}{l}\text { Parlamentarni izbori } \\
\text { 2015. godine }\end{array}$} \\
\hline & B & $\begin{array}{c}\text { Omjer } \\
\text { vjerojatnosti }\end{array}$ & $\mathrm{B}$ & $\begin{array}{c}\text { Omjer } \\
\text { vjerojatnosti }\end{array}$ & B & $\begin{array}{c}\text { Omjer } \\
\text { vjerojatnosti }\end{array}$ \\
\hline Spol (1 - muškarac) & 0,169 & 1,184 & $-0,012$ & 0,988 & 0,121 & 1,128 \\
\hline Dob & $0,030 * *$ & 1,030 & $0,018^{* *}$ & 1,018 & $0,013 * *$ & 1,013 \\
\hline Stupanj obrazovanja & $0,099 * *$ & 1,104 & $0,126^{* *}$ & 1,135 & $0,172 * *$ & 1,188 \\
\hline Veličina naselja & 0,071 & 1,074 & 0,044 & 1,045 & 0,069 & 1,072 \\
\hline $\begin{array}{l}\text { Ratna regija }(1- \\
\text { prebivalište } \mathrm{u} \text { regiji } \\
\text { zahvaćenoj ratom) }\end{array}$ & $-0,027$ & 0,974 & 0,144 & 1,155 & 0,102 & 1,107 \\
\hline Zaposlen & $0,378^{*}$ & 1,459 & 0,148 & 1,159 & $-0,198$ & 0,820 \\
\hline Nezaposlen & $-0,009$ & 0,991 & $-0,121$ & 0,886 & $-0,127$ & 0,880 \\
\hline Umirovljenik & 0,262 & 1,299 & 0,246 & 1,279 & $-0,057$ & 0,945 \\
\hline $\begin{array}{l}\text { Učestalost odlaska } \\
\text { na vjerske obrede }\end{array}$ & $0,151 * *$ & 1,163 & $0,205^{* *}$ & 1,228 & $0,156^{* *}$ & 1,169 \\
\hline $\begin{array}{l}\text { Odsustvo iskustva } \\
\text { ratne traume } \\
(1-\text { nema osobno } \\
\text { iskustvo ratne } \\
\text { traume }) \\
\end{array}$ & $0,260^{*}$ & 1,297 & 0,194 & 1,214 & 0,369 & 1,446 \\
\hline $\begin{array}{l}\text { Status branitelja } \\
(1-\text { ima status } \\
\text { branitelja })\end{array}$ & 0,025 & 1,025 & 0,073 & 1,076 & 0,095 & 1,100 \\
\hline Konstanta & $-1,836 * *$ & 0,159 & $-1,248 * *$ & 0,287 & $-1,302 * *$ & 0,272 \\
\hline $\mathrm{N}$ & \multicolumn{2}{|c|}{2672} & \multicolumn{2}{|c|}{2672} & \multicolumn{2}{|c|}{2672} \\
\hline $\begin{array}{l}\text { Pseudo R2 (Cox \& } \\
\text { Snell R Square) }\end{array}$ & \multicolumn{2}{|c|}{0,052} & \multicolumn{2}{|c|}{0,04} & \multicolumn{2}{|c|}{0,035} \\
\hline Log likelihood & \multicolumn{2}{|c|}{2605,13} & \multicolumn{2}{|c|}{2512,97} & \multicolumn{2}{|c|}{2765,47} \\
\hline $\begin{array}{l}\text { Hi-kvadrat test } \\
\text { modela }\end{array}$ & \multicolumn{2}{|c|}{$139,94 * *$} & \multicolumn{2}{|c|}{$106,98 * *$} & \multicolumn{2}{|c|}{$94,86^{* *}$} \\
\hline
\end{tabular}

$* * \mathrm{p}<0,01 ; * \mathrm{p}<0,05$ 


\section{Političke preferencije}

$\mathrm{Na}$ svim trima promatranim izborima uočljiv je isti obrazac u pogledu razlika $u$ političkim preferencijama ispitanika veterana u odnosu na ostatak uzorka: veterani u većoj mjeri glasuju za stranke ili kandidate desnice i desnog centra u odnosu na ostale ispitanike. Na parlamentarnim izborima koji su održani u prosincu 2011. godine nešto više od polovine veterana $(51,5 \%)$ u našem uzorku je glasalo za stranke desnice i desnog centra, dok je taj postotak za ne-veterane niži za oko 13 postotnih poena i iznosi $38,7 \%$ (tablica 3). S druge strane, 44,6\% ispitanika ne-veterana iz uzorka je na tim izborima glasalo za stranke ljevice i lijevog centra, dok je taj postotak među ispitanicima veteranima niži za oko 10 postotnih poena. Veterani su također u nešto većem postotku glasali za stranke centra i interesne stranke, ali su se u većem postotku i izjasnili o tom pitanju. No veća sklonost glasanju za stranke desnice i desnog centra te manja sklonost glasanju za stranke ljevice i lijevog centra $\mathrm{u}$ veteranskoj populaciji ne mogu se objasniti razlikom u sklonosti odgovaranju na to pitanje. Zaključujemo, dakle, da su opisane razlike u obrascima glasanja na parlamentarnim izborima 2011. godine između ispitanika veterana i ne-veterana statistički značajne $(\chi=20,93 ; \mathrm{df}=3 ; \mathrm{p}<0,01)$.

Isti zaključak se odnosi i na drugi krug izbora za Predsjednika Republike Hrvatske. Oko 61\% ispitanika veterana je u drugom krugu glasalo za Kolindu GrabarKitarović, dok je taj udio za oko 11 postotnih poena niži kod ne-veterana. Obrnuto, udio glasača Ive Josipovića među ispitanicima ne-veteranima je za oko 10 postotnih poena veći nego među veteranima. Razlika između dvije promatrane skupine u izjašnjavanju o tom pitanju je zanemarivo mala, tako da spremnost na odgovaranje nije mogla utjecati na navedene razlike. Opisane razlike u odabiru predsjedničkih kandidata, od kojih se jedan deklarirao kao kandidat lijevog centra, a drugi kao kandidat desnog centra, između veterana i ne-veterana su statistički značajne $(\chi=20,93$; $\mathrm{df}=3 ; \mathrm{p}<0,01)$.

Nešto manje od polovine anketiranih veterana (48\%) iskazalo je namjeru glasanja za stranke koje se mogu okarakterizirati kao stranke desnice i desnog centra na parlamentarnim izborima 2015. godine, dok je taj postotak u ostatku uzorka niži za gotovo 14 postotnih poena. S druge strane, ispitanici ne-veterani su u većoj mjeri glasali za stranke ljevice i lijevog centra $(35,2 \%$ u odnosu na $24,5 \%)$ te protestne stranke $(10,1 \%$ u odnosu na $8,1 \%)$ u odnosu na ispitanike sa statusom branitelja. Udio neodlučnih birača, to jest onih koji još nisu bili donijeli odluku za koju opciju će glasati te onih koji se nisu izjasnili, sličan je u dvije promatrane skupine. Navedene razlike su statistički značajne $(\chi=21,13 ; \mathrm{df}=4 ; \mathrm{p}<0,01)$. 
Tablica 3. Glasanje na parlamentarnim izborima 2011. godine - usporedba veterana i ne-veterana $(\%)^{8}$

\begin{tabular}{|l|c|c|c|}
\hline & Cijeli uzorak & Ne-veterani & Veterani \\
\hline Desnica i desni centar & 40,3 & 38,7 & 51,5 \\
\hline Centar i interesne stranke & 4,7 & 4,4 & 6,6 \\
\hline Ljevica i lijevi centar & 43,3 & 44,6 & 34,4 \\
\hline Bez odgovora & 11,7 & 12,3 & 7,5 \\
\hline
\end{tabular}

Tablica 4. Glasanje u drugom krugu predsjedničkih izbora 2015. godine - usporedba veterana i ne-veterana $(\%)^{9}$

\begin{tabular}{|l|c|c|c|}
\hline & Cijeli uzorak & Ne-veterani & Veterani \\
\hline Ivo Josipović & 38,7 & 39,9 & 30,0 \\
\hline Kolinda Grabar-Kitarović & 51,7 & 50,4 & 61,2 \\
\hline Bez odgovora & 9,6 & 9,7 & 8,7 \\
\hline
\end{tabular}

Tablica 5. Preferencije stranaka za parlamentarne izbore 2015. godine - usporedba veterana i ne-veterana $(\%)^{10}$

\begin{tabular}{|l|c|c|c|}
\hline & Cijeli uzorak & Ne-veterani & Veterani \\
\hline Desnica i desni centar & 35,8 & 34,2 & 48,0 \\
\hline Centar i interesne stranke & 9,9 & 9,9 & 9,9 \\
\hline Protestne stranke & 9,8 & 10,1 & 8,1 \\
\hline Ljevica i lijevi centar & 33,9 & 35,2 & 24,5 \\
\hline Neodlučni i bez odgovora & 10,5 & 10,7 & 9,5 \\
\hline
\end{tabular}

Napomena: samo ispitanici koji su iskazali namjeru izlaska na izbore.

${ }^{8}$ Stranke su grupirane prema osnovnim političkim orijentacijama na sljedeći način: desnicu i desni centar čine koalicija HDZ-HGS, HSS, HSP, koalicija HSP dr. AS i HČSP, HDSSB; centar i interesne stranke čine koalicija BUZ-PGS-RS-Ljubo Jurčić, HSLS, NL Milan Bandić, Ladonja, ostale stranke; ljevicu i lijevi centar čine koalicija SDP-HNS-IDS-HSU, Hrvatski laburisti, NL Ivana Grubišića. Opcija "bez odgovora" odnosi se na birače koji su naveli da su izašli na te izbore, ali se nisu mogli sjetiti za koju stranku su glasali ili nisu željeli odgovoriti na to pitanje.

${ }^{9}$ Ivo Josipović je na izborima osvojio veći udio glasova od dobivenog u istraživanju, dok je udio glasova Kolinde Grabar-Kitarović gotovo jednak ostvarenom. S obzirom na to da se oko $10 \%$ ispitanika nije izjasnilo o tom pitanju, možemo pretpostaviti da su to češće birači koji su glasali za Ivu Josipovića.

${ }^{10}$ Stranke su grupirane prema političkim orijentacijama na sljedeći način: desnicu i desni centar čine HDZ, HSS, HSP dr. AS, HSP, Hrvatska zora, HDSSB, Hrast, Hrvatski konzervativci; centar 
S obzirom na to da je populacija veterana u nekim socio-demografskim i socio-ekonomskim aspektima znatno homogenija od ostatka populacije te se u nekim obilježjima značajno razlikuje od strukture ostatka populacije, kao što je primjerice spolna, dobna i regionalna struktura, temeljem utvrđenih razlika na bivarijantnoj razini nije moguće sa sigurnošću zaključivati o posebnosti veterana, odnosno utvrditi veću sklonost glasanju za stranke i kandidate desnice i desnog centra. Stoga su provedene binarne logističke regresije zasebno za troje nacionalne izbore kako bismo provjerili povećava li braniteljski status vjerojatnost glasanja za stranke desnice i desnog centra kada se kontrolira doprinos ostalih obilježja koja mogu biti povezana s političkim preferencijama: spol, dob, stupanj obrazovanja, status na tržištu rada (zaposlen, nezaposlen, umirovljen), veličina naselja, prebivanje u regiji izravno pogođenoj ratom, odsustvo iskustva ratne traume te religioznost mjerena učestalošću odlaska na vjerske obrede.

U sva tri modela status hrvatskog branitelja ima statistički značajan efekt na sklonost ispitanika da glasaju za stranke desnice i desnog centra, što znači da status branitelja statistički značajno utječe na sklonost ispitanika glasanju za te stranke i kada se kontrolira utjecaj ostalih obilježja. Za troje promatrane izbore status branitelja povećava vjerojatnost glasanja za stranke ili kandidate desnice i desnog centra za oko $50 \%$, uz pretpostavku da su ostala kontrolirana obilježja ispitanika istovjetna. Status branitelja ostaje statistički značajan prediktor, s negativnim predznakom, i kad se umjesto glasanja za stranke desnice i desnog centra u modele kao zavisna varijabla uvrsti glasanje za stranke ljevice i lijevog centra. ${ }^{11} \mathrm{U}$ tom slučaju status branitelja umanjuje vjerojatnost glasanja za stranke ili kandidate ljevice i lijevog centra za 40 do 60 posto, ovisno o izborima. Ipak, treba istaknuti da od prediktora uvrštenih u model status branitelja ne spada u one s najvećim efektom. Primjerice stupanj obrazovanja ili učestalost odlaska na vjerske obrede imaju znatno veći efekt.

i interesne stranke čine umirovljeničke stranke, HGS, HSLS, Bandić Milan 365, Narodna stranka-reformisti, A-HSS, ostale stranke; protestne stranke čine Most i Živi zid; ljevicu i lijevi centar čine SDP, HNS, Hrvatski laburisti - stranka rada, IDS, ORaH, NL dr. Ivan Grubišić, SDSS, Naprijed Hrvatska. Na tim izborima značajan rezultat su ostvarile nove stranke koje se ne mogu jednoznačno svrstati u klasičnoj podjeli, kao što su Most i Živi zid, pa su one radi jasnoće izdvojene u zasebnu kategoriju. S obzirom na to da je istraživanje provedeno u periodu između srpnja i listopada 2015. godine, a da je konačna struktura koalicija bila poznata tek u rujnu, u klasifikaciji birača u političke blokove korištena je njihova preferencija pojedinačnih stranaka. Opcija "bez odgovora" odnosi se na birače koji su naveli da su izašli na te izbore ali se nisu mogli sjetiti za koju stranku su glasali ili nisu željeli odgovoriti na to pitanje.

11 Rezultati tih logističkih regresija nisu prikazani u radu zbog ekonomičnosti, a analize su provedene kao kontrola nalaza dobivenih u analizama u kojima je glasanje za stranke desnice i desnog centra korišteno kao zavisna varijabla. 
Tablica 6. Rezultati binarne logističke regresije s glasanjem za stranke desnice i desnog centra kao zavisnom varijablom

\begin{tabular}{|c|c|c|c|c|c|c|}
\hline & \multicolumn{2}{|c|}{$\begin{array}{l}\text { Parlamentarni izbori } \\
\text { 2011. godine }\end{array}$} & \multicolumn{2}{|c|}{$\begin{array}{c}\text { Drugi krug } \\
\text { predsjedničkih izbora } \\
\text { 2015. godine } \\
\end{array}$} & \multicolumn{2}{|c|}{$\begin{array}{l}\text { Parlamentarni izbori } \\
\text { 2015. godine }\end{array}$} \\
\hline & B & $\begin{array}{c}\text { Omjer } \\
\text { vjerojatnosti }\end{array}$ & $\mathrm{B}$ & $\begin{array}{c}\text { Omjer } \\
\text { vjerojatnosti }\end{array}$ & B & $\begin{array}{c}\text { Omjer } \\
\text { vjerojatnosti }\end{array}$ \\
\hline Spol (1 - muškarac) & $0,379 * *$ & 1,461 & $0,273 * *$ & 1,313 & $0,481 * *$ & 1,618 \\
\hline Dob & $-0,017 * *$ & 0,984 & $-0,02 * *$ & 0,980 & $-0,002$ & 0,998 \\
\hline Stupanj obrazovanja & $-0,133^{* *}$ & 0,875 & $-0,117^{* *}$ & 0,889 & $-0,089 * *$ & 0,915 \\
\hline Veličina naselja & $-0,091 *$ & 0,913 & $-0,101 *$ & 0,904 & $-0,197 * *$ & 0,821 \\
\hline $\begin{array}{l}\text { Ratna regija ( } 1- \\
\text { prebivalište u regiji } \\
\text { zahvaćenoj ratom) }\end{array}$ & $0,656^{* *}$ & 1,926 & $0,299 * *$ & 1,349 & $0,472 * *$ & 1,604 \\
\hline Zaposlen & $-0,333$ & 0,717 & $-0,179$ & 0,836 & $-0,283$ & 0,754 \\
\hline Nezaposlen & $-0,093$ & 0,912 & 0,319 & 1,375 & $-0,016$ & 0,984 \\
\hline Umirovljenik & $-0,011$ & 0,989 & 0,071 & 1,073 & $-0,046$ & 0,955 \\
\hline $\begin{array}{l}\text { Učestalost odlaska } \\
\text { na vjerske obrede }\end{array}$ & $0,325 * *$ & 1,384 & $0,313 * *$ & 1,368 & $0,334 * *$ & 1,396 \\
\hline $\begin{array}{l}\text { Odsustvo iskustva } \\
\text { ratne traume } \\
(1-\text { nema osobno } \\
\text { iskustvo ratne } \\
\text { traume) }\end{array}$ & 0,08 & 1,083 & $-0,159$ & 0,853 & $-0,178$ & 0,837 \\
\hline $\begin{array}{l}\text { Status branitelja } \\
(1-\text { ima status } \\
\text { branitelja })\end{array}$ & $0,385^{*}$ & 1,469 & $0,377^{*}$ & 1,459 & $0,366^{*}$ & 1,442 \\
\hline Konstanta & $-0,184$ & 0,832 & $0,72 *$ & 2,054 & $-0,983 * *$ & 0,374 \\
\hline $\mathrm{n}$ & \multicolumn{2}{|c|}{2101} & \multicolumn{2}{|c|}{2237} & \multicolumn{2}{|c|}{2173} \\
\hline $\begin{array}{l}\text { Pseudo R2 (Cox \& } \\
\text { Snell R Square) }\end{array}$ & \multicolumn{2}{|r|}{0,12} & \multicolumn{2}{|c|}{0,11} & \multicolumn{2}{|c|}{0,12} \\
\hline Log likelihood & \multicolumn{2}{|c|}{2515,87} & \multicolumn{2}{|c|}{2767,98} & \multicolumn{2}{|c|}{2497,03} \\
\hline $\begin{array}{l}\text { Hi-kvadrat test } \\
\text { modela }\end{array}$ & \multicolumn{2}{|c|}{$263,07 * *$} & \multicolumn{2}{|c|}{$245,36^{* *}$} & \multicolumn{2}{|c|}{$272,4 * *$} \\
\hline
\end{tabular}

$* * \mathrm{p}<0,01 ; * \mathrm{p}<0,05$ 
Zanimljivo je uočiti da su modeli za troje promatrane izbore vrlo slični, što ukazuje na stabilnost obrazaca glasanja hrvatskih birača. U sva su tri modela, osim statusa branitelja, značajni prediktori glasanja za stranke desnice još i spol, stupanj obrazovanja, veličina naselja, prebivanje u regiji izravno pogođenoj ratom te učestalost odlaska na vjerske obrede. Dob je statistički značajan prediktor u dva od tri slučaja promatranih izbora: parlamentarnim izborima 2011. i drugom krugu predsjedničkih izbora 2015. godine.

Valja, međutim, naglasiti da modeli imaju relativno slabu prediktivnu i eksplanatornu snagu, iako su statistički značajni. To je vidljivo iz relativno niskih iznosa pseudo-koeficijenata determinacije, ali i iz klasifikacijskih tablica, koje nisu prezentirane u ovom radu. U slučaju svih trojih izbora model točno predviđa vrijednost u zavisnoj varijabli temeljem vrijednosti u prediktorima u oko dvije trećine slučajeva, no samo u slučaju drugog kruga predsjedničkih izbora točnost klasifikacije ispitanika u zavisnoj varijabli znatno raste u odnosu na početnu soluciju u kojoj su ispitanicima slučajno dodijeljene vrijednosti na zavisnoj varijabli (s 52\% na 64\%). Taj model ujedno ima relativno visoku razinu specifičnosti jer u $68 \%$ slučajeva točno predviđa temeljem vrijednosti u prediktorima koji ispitanici će glasati za stranke desnice i desnog centra. U druga dva modela dodavanje prediktora povećava točnost klasifikacije samo za tri do šest postotnih poena, a specifičnost tih predviđanja je znatno ispod $50 \%$.

\section{Ideološka samo-identifikacija}

Na ponašanje birača u konkretnoj izbornoj situaciji utječe više čimbenika: od reputacije ključnih aktera, koalicijskih partnerstava, profila i karizmatičnosti lidera te konkretnih policy rješenja koje stranke nude do same ideološke orijentacije birača. U slučaju veteranske populacije u Hrvatskoj, iz do sada utvrđene njihove veće sklonosti glasanju za stranke desnice i desnog centra ne može se izvesti jednoznačan zaključak o ideološkoj orijentaciji tog segmenta biračke populacije s obzirom na činjenicu da su stranke s desnog spektra, posebice HDZ, prakticirale javne politike koje su rezultirale visokom razinom posebnih prava veteranske populacije. Upravo iz te činjenice izvedena je široko rasprostranjena hipoteza o klijentelističkom modelu odnosa između veterana i stranaka desnice i desnog centra, posebice HDZ-a. Stoga je za cjelovitije razumijevanje pozadine političkog ponašanja veterana kao birača potrebno nezavisno provjeriti odnos između ideološke orijentacije i veteranskog statusa. Kao indikator ideološko-političke orijentacije u ovom istraživanju smo koristili pitanje o kojem su se ispitanici trebali sami razvrstati na skali od 1 (krajnje lijevo) do 7 (krajnje desno), pri čemu je sredina skale predstavljala centar. 
U prosjeku veterani svoju političku orijentaciju opisuju statistički značajno desnijom od ostatka uzorka. Naime, prosječna vrijednost na skali ideološke samo-identifikacije za ispitanike s veteranskim statusom iznosi 4,5, dok je za ostatak uzorka 4,1 $(\mathrm{t}=-4,33 ; \mathrm{df}=349 ; \mathrm{p}<0,01) .{ }^{12}$ Naime, oko $37 \%$ ispitanika veterana je svoju političku orijentaciju odredilo u rasponu između umjereno desne i krajnje desne, dok to ne-veterani čine za oko 10 postotnih poena manje. Zanimljivo je da veći dio navedene razlike odlazi na kategoriju "krajnje desno", s obzirom na to da je navedeni odgovor odabralo nešto više od $14 \%$ ispitanika veterana u odnosu na oko 6\% ispitanika ne-veterana. Razlika proporcija veterana i ne-veterana koji su svoju političku orijentaciju odredili kao lijevu (od krajnje lijevo do umjereno lijevo) ili kao centar je znatno manja. Oko $25 \%$ ispitanika ne-veterana svoju političku orijentaciju opisuje u rasponu između krajnje lijevo i umjereno lijevo, dok je taj udio među veteranima niži za oko dva postotna poena. Gotovo podjednak broj ispitanika veterana i ne-veterana svoju političku orijentaciju opisuje u terminima centra (27\% u odnosu na $26 \%)$. Iz navedenog proizlazi da postoji znatna razlika u postotku onih koji su se izjasnili o ovom pitanju između dviju promatranih skupina, pri čemu se $13 \%$ veterana nije izjasnilo o političkoj orijentaciji, dok je taj udio kod ne-veterana $8 \%$ viši.

Veteranski status ostaje statistički značajan prediktor ideološke samo-identifikacije i kada se u regresiji kontrolira utjecaj drugih relevantnih obilježja ispitanika (tablica 8). Uz status branitelja, u linearnoj regresiji značajni prediktori političke samo-identifikacije su još i spol, dob (s negativnim predznakom), stupanj obrazovanja (s negativnim predznakom), veličina naselja (s negativnim predznakom), prebivalište u regiji zahvaćenoj ratom, učestalost odlaska na vjerske obrede te odsustvo ratne traume (s negativnim predznakom). Mjereno standardiziranim beta koeficijentom najsnažniji prediktori ideološke samo-identifikacije iz odabranog seta su učestalost odlaska na vjerske obrede, prebivalište u regiji zahvaćenoj ratom i dob. Status veterana spada u manje snažne prediktore. Model ima osrednju eksplanatornu snagu s vrijednosti R koeficijenta od 0,38 .

12 Korišten je t-test za uzorke nehomogenih varijanci, zbog čega broj stupnjeva slobode ne odgovara stvarnom broju ispitanika. 
Tablica 7. Skala ideološke samo-identifikacije - usporedba veterana i ne-veterana (\%)

\begin{tabular}{|l|c|c|c|}
\hline & Cijeli uzorak & Ne-veterani & Veterani \\
\hline Krajnje lijevo & 3,0 & 3,1 & 1,7 \\
\hline Lijevo & 3,2 & 3,2 & 2,6 \\
\hline Umjereno lijevo & 19,0 & 19,1 & 18,5 \\
\hline Centar & 26,3 & 26,2 & 27,3 \\
\hline Umjereno desno & 17,1 & 17,4 & 15,4 \\
\hline Desno & 4,8 & 4,5 & 7,5 \\
\hline Krajnje desno & 6,5 & 5,5 & 14,2 \\
\hline Ne zna & 12,4 & 13,1 & 7,0 \\
\hline Ne želi odgovoriti & 7,7 & 7,9 & 5,9 \\
\hline Prosjek & 4,1 & 4,1 & 4,5 \\
\hline Standardna devijacija & 1,4 & 1,4 & 1,5 \\
\hline
\end{tabular}

Tablica 8. Rezultati linearne regresije sa skalom ideološke samo-identifikacije kao zavisnom varijablom

\begin{tabular}{|l|c|}
\hline & Standardizirani Beta koeficijent \\
\hline Spol $(1-$ muškarac $)$ & $0,096^{* *}$ \\
\hline Dob & $-0,124^{* *}$ \\
\hline Stupanj obrazovanja & $-0,073^{* *}$ \\
\hline Veličina naselja & $-0,075^{* *}$ \\
\hline $\begin{array}{l}\text { Ratna regija } \\
(1-\text { prebivalište u regiji zahvaćenoj ratom })\end{array}$ & $0,14^{* *}$ \\
\hline Zaposlen & 0,039 \\
\hline Nezaposlen & 0,030 \\
\hline Umirovljenik & 0,073 \\
\hline Učestalost odlaska na vjerske obrede & $0,272^{* *}$ \\
\hline $\begin{array}{l}\text { Odsustvo iskustva ratne traume } \\
(1-\text { nema osobno iskustvo ratne traume })\end{array}$ & $-0,04 *$ \\
\hline Status branitelja (1 - ima status branitelja) & $0,061^{* *}$ \\
\hline$R^{2}$ & 0,144 \\
\hline
\end{tabular}

${ }^{* *} \mathrm{p}<0,01 ; * \mathrm{p}<0,05$ 


\section{Diskusija}

Cilj ovog rada jest ustanoviti posebnost veteranske populacije u Hrvatskoj u području političke participacije i političkih preferencija. Istraživačke hipoteze su bile da ratni veterani posjeduju višu stopu političke participacije od ne-veteranske populacije, da ratni veterani preferiraju stranke desnice i desnog centra u podjednakoj mjeri kao i pripadnici ne-veteranske populacije te da se ratni veterani ideološki samo-identificiraju podjednako kao i pripadnici ne-veteranske populacije. Nijedna od tih hipoteza u konačnici nije potvrđena.

Što se tiče prve hipoteze o političkoj participaciji, dosadašnja istraživanja su bilježila višu stopu participacije veterana i te razlike su autori tumačili socijalizacijskim faktorima vojne službe, ratnim iskustvima i viktimizacijom te poslijeratnim faktorima poput učinaka veteranskih integracijskih programa. Ako razmotrimo hrvatski kontekst i hrvatska veteranska iskustva, primjećujemo da uobičajena objašnjenja socijalizacijskih učinaka koja su nastala u SAD-u većim dijelom nisu adekvatna za naš slučaj. Naime, za očekivati je ograničene institucionalne socijalizacijske učinke u slučaju nacije koja je vojnu instituciju izgrađivala tijekom rata $i$ gdje ratni veterani u značajnom dijelu nisu imali iskustvo prolaska kroz sustav vojnog odgoja i obrazovanja u dužem vremenskom razdoblju. Također, karakter rata u Hrvatskoj u kojem je značajan segment civilne populacije bio izložen različitim oblicima izravne i neizravne viktimizacije može biti razlog relativnoj slabosti doprinosa tih čimbenika isključivo političkoj participaciji veteranske populacije. Da je karakter rata općenito važna varijabla u istraživanjima ratnih veterana govori i studija Dandekera i suradnika (2006) u kojoj se zaključuje da na službena zakonska određenja veterana, uz civilno-vojne odnose i strukturu oružanih snaga, značajno utječe i narav rata te uključenost civilnog stanovništva. U tom smislu bi moglo biti produktivno oblikovati provedbu budućih istraživanja koja bi nastojala testirati hipotezu o posttraumatskom rastu i povezanosti viktimizacije i političke participacije na razini kućanstava kao što je to slučaj s istraživanjem Bellowsa i Miguela (2009). Kad je pak riječ o poslijeratnim čimbenicima izdvojenima u dosadašnjim studijama, valja zabilježiti da se oni dominantno tiču američkog slučaja. Američki sustav veteranskih programa i socijalne politike je ne samo različit od europskih iskustava i tradicija nego ga neki autori smatraju i specifičnim oblikom socijalne politike alternativnog modela države blagostanja (Skocpol, 1993; Campbell, 2004; Klingler i Chatagnier, 2014). Za Hrvatsku je pak karakterističan drugačiji model u kojem postoji široka lepeza mjera u različitim područjima, od obrazovanja i zapošljavanja do stambene politike, koje su usmjerene korisnicima različitih društvenih skupina i gdje socijalni programi namijenjeni veteranskoj populaciji, iako unutar posebnog sustava, predstavljaju pretežno dodatne mjere skrbi. Na taj način možemo onda protumačiti i rezultate analize hrvatskog sustava veteranske skrbi koji govore da je on 
primarno orijentiran kompenzacijski, a ne integracijski (Dobrotić, 2008). S druge strane, valja podsjetiti da je jednakost političke participacije važna s gledišta demokracije i stabilnosti političkih institucija. To pitanje ima posebnu važnost za tranzicijske i postkonfliktne sredine u kojima bi više stope političke participacije bilo koje simbolički važne skupine mogle imati negativne posljedice na demokratsku konsolidaciju, jednako kao što bi niže stope mogle upućivati na isključenost ratnih veterana ili neke druge simbolički važne skupine iz političkog života i višu izloženost potencijalnom angažmanu u neinstitucionalnim oblicima političkog djelovanja (Söderström, 2015). U tom smislu rezultati ovoga istraživanja u pogledu političke participacije ratnih veterana u Hrvatskoj odgovaraju poželjnoj slici za tranzicijska društva.

Kada je riječ o političkim preferencijama i ideološkoj samo-identifikaciji, ratni veterani se statistički značajno razlikuju od ostatka biračkog tijela. Rezultati u tom području odstupaju od većine istraživanja rađenih pretežno u SAD-u. S druge strane, takvi rezultati su u suglasju sa stavovima koje možemo naći u domaćim medijskim komentarima, kao i dosadašnjim kvalitativnim studijama hrvatskih veteranskih politika (npr. Stubbs i Zrinščak, 2012; Fisher, 2003). Tri su moguća objašnjenja tih razlika, pri čemu valja naglasiti da iz podataka prezentiranih u ovome radu nije moguće posve jednoznačno otkloniti ili potvrditi neko od njih. Prvo tumačenje bi počivalo na pretpostavci selekcijske pristranosti, što bi značilo da su u ratu u većoj mjeri sudjelovali oni koji su a priori bili više patriotski i nacionalno orijentirani i u većoj mjeri politički konzervativni te da su onda prethodne političke preferencije i identiteti zadržani i preneseni u poslijeratni civilni politički život. Drugo tumačenje počiva na socijalizacijskoj paradigmi i ono bi glasilo da je iskustvo sudjelovanja $u$ ratu značajno utjecalo na tu skupinu hrvatskih građana na način da su im vrijednosti poput patriotizma, autoriteta, jake države i druge vrijednosti koje tradicionalno zastupaju desne političke opcije važnije nego ostalim građanima. Slično tome, ratno i postratno iskustvo moglo je utjecati na oblikovanje specifičnog veteranskog identiteta i specifičnih interesa veterana koji su više u suglasju s programima desnih političkih stranaka odnosno signalima koje desne političke stranke upućuju biračkom tijelu (primjerice pitanja nacionalne sigurnosti i veteranskih beneficija). Razmjena socijalnih prava za političku podršku kao oblik "socijalnog klijentelizma" (Stubbs i Zrinščak, 2012) također se može promatrati kao sastavni dio signaliziranja spremnosti na brigu o interesima veteranske populacije. Konačno, posljednje objašnjenje ustanovljenih razlika naglašava ulogu veteranskih organizacija u mobilizaciji veteranske populacije i usmjeravanju političkih preferencija. To objašnjenje preteže u studijama koje pitanjima veterana pristupaju iz istraživačke perspektive društvenih pokreta. Istraživači su u pravilu takvu ulogu veteranskih udruženja u zapadnim zemljama skloniji isticati prilikom tumačenja političkog ponašanja veterana u pr- 
voj polovici 20. stoljeća, dočim za kasnija razdoblja prevladava stav da veteranska udruženja nemaju značajnu ulogu zbog smanjenja homogenosti članstva i načina djelovanja veteranskih organizacija. S druge strane, za zemlje u poraću djelovanje veteranskih organizacija bi moglo imati određenu eksplanatornu vrijednost.

Precizniji odgovori na pitanja o čimbenicima koji utječu na posebnost ratnih veterana u pogledu političkih preferencija i samo-identifikacije ostaju za buduća istraživanja koja mogu produbiti spoznaje u ovom slabo istraženom području. Preostaje također da se istraže razlike između pojedinih skupina veterana (primjerice dragovoljci i unovačeni) kao i determinante različitih drugih oblika političke participacije.

\section{Zaključak}

U radu su prezentirani rezultati anketnog istraživanja posebnosti političkog ponašanja hrvatskih ratnih veterana. Analizirali smo veteransku i ne-veteransku skupinu ispitanika prema odgovorima koje su dale na pitanja u vezi s političkom participacijom, političkim preferencijama i ideološkom samo-identifikacijom. Istraživačke hipoteze generirane na temelju istraživanja provedenih u drugim zemljama nisu potvrđene. Hrvatski ratni veterani se ne razlikuju od ostatka nacionalnog biračkog tijela po stopi političke participacije, koju smo mjerili izlaznošću na parlamentarne izbore 2011. i 2015. godine te predsjedničke izbore 2015. godine. No, ratni veterani se razlikuju od ostatka biračkog tijela po političkim preferencijama i ideološkoj samo-identifikaciji, i to u smislu da u većoj mjeri biraju stranke desnice i desnog centra te svoju političku orijentaciju određuju kao desnu, neovisno o drugim obilježjima. Međutim, valja naglasiti kako je populacija hrvatskih veterana Domovinskog rata ipak politički pluralna društvena skupina u kojoj je zastupljen cijeli dijapazon političkih orijentacija i preferencija kao i u ostatku populacije, te da sam braniteljski status ne spada među najjače prediktore političkog ponašanja. Određenje čimbenika koji leže u podlozi veteranske posebnosti u pogledu političkih preferencija i ideološke samo-identifikacije ostaje za buduća istraživanja. Rezultati ovog istraživanja govore da postoji empirijska podloga koja ukazuje na potrebu dubljeg istraživanja veteranskog političkog ponašanja i stavova. 


\section{LITERATURA}

Bellows, John i Miguel, Edward. 2009. War and local collective action in Sierra Leone. Journal of Public Economics, (93), 11-12: 1144-1157. Doi: 10.1016/j.jpubeco.2009.07.012.

Bettelheim, Bruno i Janowitz, Morris. 1950. Dynamics of Prejudice. A Psychological and Sociological Study of Veterans. Harper\&Brothers. New York.

Blattman, Christopher. 2009. From Violence to Voting: War and Political Participation in Uganda. The American Political Science Review, (103), 2: 231-247. Doi: 10.1017/ S0003055409090212.

Campbell, Alec. 2004. The Invisible Welfare State: Establishing the Phenomenon of Twentieth Century Veteran's Benefits. Journal of Political and Military Sociology, (32), 2: 249-267.

Dandeker, Christopher, Wessely, Simon, Iversen, Amy i Ross, John. 2006. What's in a Name? Defining and Caring for 'Veterans': The United Kingdom in International Perspective. Armed Forces and Society, (32), 2: 161-177. Doi: 10.1177/0095327X05279177.

Dobrotić, Ivana. 2008. Sustav skrbi za branitelje iz Domovinskog rata. Revija za socijalnu politiku, (15), 1: 57-83. Doi: 10.3935/rsp.v15i1.712.

Dolenec, Danijela. 2014. The Rise of Organised Intolerance in Croatia. Rad prezentiran na konferenciji: Fringe Politics II: Conservative Social Movements and the Mainstreaming of Extremism in Southeast Europe. Sveučilište u Grazu, 19-20. ožujka 2014.

Elder, Glen H. i Clipp, Elizabeth C. 1989. Combat Experience and Emotional Health: Impairment and Resilience in Later Life. Journal of Personality, (57), 2: 311-341. Doi: 10.1111/j.1467-6494.1989.tb00485.x.

Ellison, Christopher G. 1992. Military Background, Racial Orientations, and Political Participation among Black Adult Males. Social Science Quarterly, (73), 2: 360-378.

Fisher, Sharon. 2003. Contentious politics in Croatia. The war veterans' movement, u: Kopecky, P. i Mudde, C. (ur.): Uncivil Society? Contentious politics in post-communist Europe. Routledge. London i New York: 74-92.

Jenning, Kent M. i Markus, Gregory B. 1977. The Effect of Military Service on Political Attitudes: A Panel Study. The American Political Science Review, (71), 1: 131-147. Doi: $10.1017 / \mathrm{S} 0003055400259340$.

Kasapović, Mirjana. 2001. Demokratska konsolidacija i izborna politika u Hrvatskoj, u: Kasapović, M. (ur.): Hrvatska politika 1990.-2000. Izbori, stranke i parlament u Hrvatskoj. Fakultet političkih znanosti. Zagreb: 15-40.

Klingler, Jonathan D. i Chatagnier, Tyson J. 2014. Are You Doing Your Part? Veterans' Political Attitudes and Heinlein's Conception of Citizenship. Armed Forces \& Society, (40), 4: 673-695. Doi: 10.1177/0095327X12471932. 
Leal, David L. 1999. It's Not Just a Job: Military Service and Latino Political Participation. Political Behavior, (21), 2: 153-174. Doi: 10.1023/A:1022038816779.

Leal, David L. i Teigen, Jeremy M. 2015. Recent veterans are more Republican than older ones. Why? The Washington Post, 11. 11. 2015. URL: https://www.washingtonpost.com/news/monkey-cage/wp/2015/11/11/recent-veterans-are-more-republican-than-older-ones-why/.

Mettler, Suzanne. 2002. Bringing the State Back In to Civic Engagement: Policy Feedback Effects of the G.I. Bill for World War II Veterans. American Political Science Review, (96), 2: 351-365. Doi: 10.1017/S0003055402000217.

Nesbit, Rebecca i Reingold, David A. 2011. Soldiers to Citizens: The Link between Military Service and Volunteering. Public Administration Review, (71), 1: 67-76. Doi: 10.1111/j.1540-6210.2010.02307.x.

Parker, Christopher S. 2009. When Politics Becomes Protest: Black Veterans and Political Activism in the Postwar South. The Journal of Politics, (71), 1: 113-131. Doi: $10.1017 / \mathrm{S} 0022381608090087$.

Schreiber, E. M. 1978. Enduring Effects of Military Service? Opinion Differences between U.S. Veterans and Nonveterans. Social Forces, (57), 3: 824-839.

Skocpol, Theda. 1993. America's First Social Security System: The Expansion of Benefits for Civil War Veterans. Political Science Quarterly, (108), 1: 85-116. Doi: $10.2307 / 2152487$.

Söderström, Johanna. 2015. Peacebuilding and Ex-Combatants. Political reintegration in Liberia. Routledge. London.

Stubbs, Paul i Zrinščak, Siniša. 2012. Klijentelizam i socijalna politika, u: Zakošek, N. (ur.): 2. Zagrebački ekonomski forum. Friedrich Ebert Stiftung. Zagreb: 5-19.

Šućur, Zoran, Babić, Zdenko i Ogresta, Jelena. 2017. Demografska i socioekonomska obilježja Hrvatskih branitelja prema Popisu stanovništva, kućanstava i stanova 2011. godine. Ministarstvo hrvatskih branitelja i Državni zavod za statistiku. Zagreb.

Tedeschi, Richard G. i Calhoun, Lawrence G. 2004. Posttraumatic Growth: Conceptual Foundations and Empirical Evidence. Psychological Inquiry, (15), 1: 1-18. Doi: 10.1207/s15327965pli1501_01.

Teigen, Jeremy M. 2006. Enduring Effects of the Uniform: Previous Military Experience and Voting Turnout. Political Research Quarterly, (59), 4: 601-607. Doi: $10.1177 / 106591290605900409$.

Teigen, Jeremy M. 2007. Veterans' Party Identification, Candidate Affect, and Vote Choice in the 2004 U.S. Presidential Election. Armed Forces \& Society, (33), 3: 414437. Doi: $10.1177 / 0002764206296586$.

Teigen, Jeremy M. 2012. Conventional and Distinctive Policy Preferences of EarlyTwenty-First-Century Veterans, u: Ortiz S. R. (ur.): Veterans' Policies, Veterans' 
Politics. New Perspectives on Veterans in the Modern United States. University Press of Florida. Gainesville: 263-280.

Vlada Republike Hrvatske. 2014. Izvješće o provedbi Zakona o pravima hrvatskih branitelja iz Domovinskog rata i članova njihovih obitelji za 2013. godinu. Dostupno na: https://vlada.gov.hr.

\author{
Dragan Bagić, Kruno Kardov \\ POLITICAL PARTICIPATION AND PARTY PREFERENCES \\ AMONG WAR VETERANS IN CROATIA
}

\begin{abstract}
Summary
The paper examines distinctiveness of war veterans compared to general population in Croatia according to three important political phenomena: political participation, party preferences and ideological self-identification. Analysis of sociological survey conducted in 2015 shows that there is no difference in the level of political participation measured by voting turnout in 2011 and 2015 parliamentary and 2015 presidential level between Croatian war veterans and the rest of the public. On the other side, war veterans differ from the rest of the electorate, with other variables held constant, in terms of party preferences and ideological self-identification. Compared to non-veterans, war veterans are more inclined to vote for the right and center-right parties and position themselves to the right side of the political spectrum. The paper discusses these differences, as well as its roots and consequences.
\end{abstract}

Keywords: Elections, Political Participation, Political Behaviour, Party Preferences, Croatian War Veterans

Dragan Bagić je izvanredni profesor na Odsjeku za sociologiju Filozofskog fakulteta Sveučilišta u Zagrebu.

Kruno Kardov je docent na Odsjeku za sociologiju Filozofskog fakulteta Sveučilišta u Zagrebu.

Kontakti:

Dragan Bagić, Odsjek za sociologiju, Filozofski fakultet Sveučilišta u Zagrebu, I. Lučića 3, 10000 Zagreb. E-mail: dbagic@ffzg.hr

Kruno Kardov, Odsjek za sociologiju, Filozofski fakultet Sveučilišta u Zagrebu, I. Lučića 3, 10000 Zagreb. E-mail: kkardov@ffzg.hr 